Review Article COVID-19 - Special Issue

\title{
SARS-CoV-2 and COVID-19: A perspective from environmental virology
}

\author{
Meriane Demoliner ${ }^{1,2}$ (D), Juliana Schons Gularte ${ }^{1,2}$, Viviane Girardi ${ }^{1}$, Paula Rodrigues de Almeida ${ }^{1,2}$, \\ Matheus Nunes Weber ${ }^{1,3}$, Ana Karolina Antunes Eisen ${ }^{1,3}$, Juliane Deise Fleck ${ }^{1,2,3}$ and Fernando Rosado Spilki ${ }^{1,2,3}$ \\ ${ }^{1}$ Universidade Feevale, Laboratório de Microbiologia Molecular, Novo Hamburgo, RS, Brazil. \\ ${ }^{2}$ Universidade Feevale, Programa de Pós-Graduação em Qualidade Ambiental, Novo Hamburgo, RS, Brazil. \\ ${ }^{3}$ Universidade Feevale, Mestrado Acadêmico em Virologia, Novo Hamburgo, RS, Brazil.
}

\begin{abstract}
December 2019 marked the beginning of the current Coronavirus disease pandemic (COVID-19). Severe acute respiratory syndrome-related coronavirus 2 (SARS-CoV-2) was identified as the causative agent of a viral pneumonia outbreak in Wuhan, Hubei Province, China. The alarming spread levels and clinical severity elevated the status of COVID-19 to the global pandemic by the World Health Organization. In 6 months, more than 25 million cases of infected people and more than 890,000 deaths by COVID-19 had been reported worldwide. The main goal of this review is to shed light upon the current COVID-19 epidemic situation in Brazil with a health approach highlighting some unique environmental, animal and epidemiological aspects.
\end{abstract}

Keywords: SARS-CoV-2, COVID-19, environmental virology, Brazil, disease pandemic.

Received: July 02, 2020; Accepted: January 18, 2021.

\section{Introduction}

Severe acute respiratory syndrome-related coronavirus 2 (SARS-CoV-2), initially named Novel coronavirus (2019$\mathrm{nCoV}$ ), is the causative agent of the current Coronavirus disease 2019 (COVID-19) pandemic (Gorbalenya et al., 2020). SARS-CoV-2 belongs to the Coronaviridae family (subfamily Coronavirinae) which includes four genera, Alpha-, Beta-, Gamma- and Delta-coronavirus. Only alpha and betacoronaviruses are known to infect humans, of which human coronavirus (HCoV)-229E and HCoV-NL63 are classified as alphacoronaviruses, while HCoV-HKU1, HCoV-OC43, Middle East respiratory syndrome coronavirus (MERS-CoV), SARS-CoV, and SARS-CoV-2 are grouped within the Betacoronavirus genus.

The subgenus Sarbecovirus comprises SARS-CoV and SARS-CoV-2, which are classified in the same species: SARS-related coronavirus (SARSr-CoV) (Cui et al., 2019). This viral family is characterized by significant genetic variability and a high recombination rate that enable them to be easily distributed among humans and animals worldwide. Coronaviruses are enveloped and have a positive-sense singlestranded RNA genome of approximately $30 \mathrm{~kb}$, ranging from $60-220 \mathrm{~nm}$ in size with crown-like spike proteins on their surfaces that bind to host cell proteins allowing viral entry (Tu et al., 2020).

In December 2019, this virus caused viral pneumonia in Wuhan, Hubei Province, China, being identified in the first week of 2020 with fast dissemination throughout China and surrounding countries (Jin et al., 2020). The alarming levels and severity of its spreading elevated the status of COVID-19 to the global pandemic by the World Health Organization (WHO) on March $11^{\text {th }}, 2020$. On that date, the number of

Send correspondence to Meriane Demoliner. Universidade Feevale, Laboratório de Microbiologia Molecular, 93525-075, Novo Hamburgo, RS, Brazil. E-mail: merianedemoliner@gmail.com. cases outside China had increased 13-fold and the number of affected countries had tripled (more than 118,000 cases in 114 countries, 4,291 deaths) (WHO, 2020a).

The epidemiological situation worldwide has been changing since the beginning of the outbreak. According to WHO (2020b), the Western Pacific region had the majority of the daily confirmed cases in the first months. After that, the situation had rapidly changed and the highest daily confirmed cases occurred in the Eastern Mediterranean region at the beginning of March, followed by Europe from March to April, alternating some days with the Americas, and since April $21^{\text {st }}$ the Americas have been showing the highest numbers so far (data updated on September $9^{\text {th }}, 2020$ ). By the beginning of September of 2020, more than 25 million cases and more than 890,000 deaths due COVID-19 have been reported worldwide (WHO, 2020b, c).

In Europe, the first patient was diagnosed with COVID-19 on January $24^{\text {th }}, 2020$, a 48-year-old French woman who came from China (Lescure et al., 2020). On September 2020, the country in Europe with the highest number of infected people was the Russian Federation, with more than 1 million confirmed cases (WHO, 2020b).

In the Americas region, the United States of America (USA) and Brazil have the highest numbers of confirmed cases and deaths from COVID-19 (WHO, 2020b, c). In the USA, the first case of COVID-19 was reported on January $19^{\text {th }}, 2020$, a 35 -year-old man in the Snohomish County, Washington, with a four-day history of cough and fever. He revealed that he had returned to Washington State on January $15^{\text {th }}$, after traveling to visit his family in Wuhan, China (Holshue et al., 2020). In September 2020, the total number of confirmed cases in the USA was more than 6 million (WHO, 2020b).

In Latin America, the first case of COVID-19 was confirmed in Brazil by the Ministry of Health on February $25^{\text {th }}, 2020$. The case was a Brazilian man, 61 years-old, who traveled from February $9^{\text {th }}$ to $20^{\text {th }}, 2020$, to Lombardy, Northern 
Italy (Rodriguez-Morales et al., 2020). In September 2020, Brazil already had more than 4 million confirmed cases and more than 100 thousand deaths (WHO, 2020b). The current data showed that four out of ten countries with the highest number of infections were from South America (Brazil, Peru, Colombia and Argentina) (WHO, 2020c). Globally, in September 2020, the Americas had the highest number of infected people, more than 14 million cases; while the Western Pacific had the lowest number with about 500 thousand cases. In relation to the highest number of deaths, the Americas recorded the highest number, almost 500 thousand deaths, and Western Pacific had the lowest with about 11 thousand deaths (WHO, 2020b, c).

The main goal of this review is to shed light upon the current COVID-19 epidemic situation in Brazil with a health approach, highlighting some unique environmental, animal and epidemiological peculiarities that impose challenges to overcome this situation in a society with high levels of inequality. Environmental factors are associated with the spillover of SARS-CoV-2 and might constitute the main driving source of the persistence of the pandemics.

\section{The spread of SARS-CoV-2 in Brazil}

São Paulo-Guarulhos International Airport, located in the State of São Paulo, is the largest airport in Brazil and this city is the most populated in South America ( $>23$ million people). Furthermore, besides the high air traffic connecting Brazil with cities in Latin America, North America, Europe, Africa and the Middle East, there are usual connections with metropolitan centers of Paraguay, Argentina, Uruguay and Bolivia by roads and bus services, and with Chile, Argentina and Bolivia by some railways (Rodriguez-Morales et al., 2020).

So, without border control, the spread of SARS-CoV-2 through these routes is probably inevitable. According to Candido et al. (2020), it is estimated that $54.8 \%$ of SARSCoV-2 introductions in Brazil came from travelers infected in Italy, 9.3\% in China and $8.3 \%$ in France. Only the route Italy - São Paulo could be responsible to comprise $24.9 \%$ of the total of travelers with COVID-19 flying to Brazil during this period.

COVID-19 was declared a pandemic on March $11^{\text {th }}$, 2020 , but only on March $27^{\text {th }}$, the Brazilian government issued a new ordinance (No. 152) restricting the entry of foreigners of all nationalities to Brazil (Governo Federal do Brasil, 2020). On the same day the Centers for Disease Control and Prevention (CDC) issued a Global COVID-19 Level 3 Warning recommending that travelers avoided all nonessential international travels (CDC, 2020a).

As of March $30^{\text {th }}, 2020$, there was no official protocol for SARS-CoV-2 testing in ports, airports and borders; the only measure adopted by the National Health Surveillance Agency (Agência Nacional de Vigilância Sanitária - ANVISA) was to identify symptomatic cases of COVID-19 at such locations (ANVISA, 2020). However, only symptom screening of incoming passengers may not be effective to reduce the global spread of SARS-CoV-2, as a large proportion of infected travelers may be asymptomatic or presymptomatic. That way, to decrease the risk of importation of cases to other countries it is necessary to improve the tracing within the epicenters (Wells et al., 2020).
As described above, SARS-CoV-2 was first reported in Brazil from a traveler coming from Italy. At the beginning of SARS-CoV-2 spread in Brazil, most of the diagnosis was performed in higher-income people (Souza et al., 2020). People with that social condition, for example, traveled more during summer vacation and many were infected abroad. Thus, the infection to low-income people that comprises most of the Brazilian population occurred later. Another Brazilian study showed that less-educated adults presented a 2-fold higher prevalence of SARS-CoV-2 infections (Rezende et al., 2020).

A few weeks after the first detection in Brazil, local transmission was already established in several foci (Souza et al., 2020), and once the virus reached the low-income classes, control measures became more difficult to be taken since several official diagnostic laboratories became initially overwhelmed. Currently, the lack of personnel and laboratory material to meet the demand for diagnosis in official government laboratories has been met by hospitals and research groups from universities in several Brazilian states.

\section{Regional climate and SARS-CoV-2 transmission}

In the past, a study showed that high temperatures and high relative humidity have a negative effect on SARS-CoV viability, while lower temperatures and low humidity can be a benefit to prolong virus survival on contaminated surfaces (Chan et al., 2011). In the beginning, the first studies with SARS-CoV-2 showed similar stability to that of SARS-CoV, for which the main results demonstrated that at $65 \%$ relative humidity and $21-23{ }^{\circ} \mathrm{C}$ temperature the virus can be viable in the air for up 3 hours (Van Doremalen et al., 2020).

When the stability of SARS-CoV-2 is evaluated at different temperatures, it is possible to observe that this virus is highly stable at $4{ }^{\circ} \mathrm{C}$ and sensitive to the heat. As the temperature rises, the time that the virus remains viable decreases, for example, at $22{ }^{\circ} \mathrm{C}$ the virus can remain viable for 7 days, at $37^{\circ} \mathrm{C}$ for 1 day, at $56^{\circ} \mathrm{C}$ for 10 minutes and at $70{ }^{\circ} \mathrm{C}$ for 1 minute (Chin et al., 2020).

Brazil is a large tropical country with most of its territory located between the Equator and the Tropic of Capricorn. A Brazilian study about the effect of tropical weather on SARSCoV-2 transmission did not identify evidence of a negative correlation on COVID-19 infection in higher temperatures (above $25^{\circ} \mathrm{C}$ ). However, below the threshold of $25.8^{\circ} \mathrm{C}$, the cases decreased by -5.9035 for every $1{ }^{\circ} \mathrm{C}$ rise in temperature (Prata et al., 2020).

The highest annual temperature means are usually in the North and the lowest in the South, however, the South of Brazil is the region that has been presenting the lowest number of cases and deaths per million inhabitants so far (data updated on August 15 $5^{\text {th }}, 2020$ ) (Table 1) and showed an increase in case numbers later when compared to other states.

On the other hand, in the first months of the pandemic, the Northeast and North regions have quickly shown a spread in cases and death numbers, being only behind the Southeast region. The North region has also shown the highest number of deaths per million inhabitants (Table 1). These data show us that questions regarding the regional differences of a country as large and diverse as Brazil may have a more relevant influence 
Table 1 - Number of cases and deaths by COVID-19 in different regions of Brazil*.

\begin{tabular}{|c|c|c|c|c|}
\hline \multirow[b]{2}{*}{ Region of Brazil } & \multicolumn{2}{|c|}{ Cases of COVID-19 } & \multicolumn{2}{|c|}{ Deaths by COVID-19 } \\
\hline & Cumulative number & Per million inhabitants & Cumulative number & Per million inhabitants \\
\hline Southeast & $1,158,423$ & $1,310.90$ & 48,214 & 54.6 \\
\hline Northeast & $1,018,476$ & $1,784.60$ & 32,108 & 56.30 \\
\hline North & 473,725 & $2,570.30$ & 12,670 & 68.7 \\
\hline South & 321.217 & $1,071,60$ & 7,079 & 23.6 \\
\hline Center-West & 345,255 & $2,188.50$ & 7,161 & 43.9 \\
\hline
\end{tabular}

*The data of cases and deaths of COVID-19 in the regions of Brazil for the 33rd epidemiological week was obtained from the 27th Special Epidemiological Bulletin COE-COVID-19 published by the Ministry of Health and the Health Surveillance Secretariat (SVS) of Brazil (Ministério da Saúde do Brasil, 2020).

on the spread and aggravation of the disease when compared to abiotic issues.

\section{Social distancing}

To reduce SARS-CoV-2 transmission, an early implementation of social distancing has proven effective in many countries. Also, it is much important to accelerate and expand testing to obtain data more accurately in order to be able to track positive cases and contact people who had been in contact with those cases to better control COVID-19 spread (Bedford et al., 2020; de Oliveira et al., 2020). Since there are no COVID-19 vaccines widely available so far, non-pharmacological interventions like social distancing, quarantine and isolation of infected individuals are important alternatives to reduce transmission and slow the SARSCoV-2 spread (Wilder-Smith and Freedman, 2020). Therefore, flexible social distancing measures must be made with extreme caution.

The Brazilian Inloco startup developed a map showing the percentage of the population that is respecting the isolation recommendation during the COVID-19 pandemic based on the location of their cell phones, and although it is not possible to represent the total population it is possible to have an approximate number of the Social Isolation Index. The data demonstrated that the higher index achieved on May $22^{\text {nd }}$, 2020 , where the Social Isolation Index was $62.6 \%$, this number has been falling, and on June $26^{\text {th }}, 2020$, the index was $37.5 \%$ (Inloco, 2020).

On May $8^{\text {th }}, 2020$, in its Report 21 , the Imperial College COVID-19 Response Team published that in Brazil, so far, the changes in mobility have not been stringent enough to reduce the transmission number and it is possible to project a continued growth of the epidemic. Therefore, if the government does not adopt harder control measures the virus will still have enough hosts to infect, the epidemic will continue to grow exponentially and the associated number of cases and deaths will therefore increase (Mellan et al., 2020).

\section{Initiatives of Brazilian research groups to help in the SARS-CoV-2 pandemic}

In Brazil there are State Central Laboratories (Laboratórios Centrais de Saúde Pública - LACEN) that belong to the National System of Public Health Laboratories (Sistema Nacional de Laboratórios de Saúde Pública SISLAB). Currently, they do the most of the diagnosis of SARS-CoV-2. However, only these institutions and private diagnosis labs are not enough to cover the high diagnosis demand imposed by the COVID-19 pandemic.

Therefore, to contribute to a faster and efficient national response to the present pandemic, many research groups offered their labs and expertise to accelerate the diagnosis. The tests done in the laboratories from public and private universities counted mainly with the help from researchers and student volunteers. However, even with these efforts the number of COVID-19 tests performed is still low.

According to the Worldometer Website (September 2020), Brazil occupies the rank position in the number of tests performed and $10^{\text {th }}$ in the number of confirmed cases per 1 million people. Mass testing is seen as an important method to identify the positive cases and apply public health measures in time. These actions help to slow transmission and develop strategies to decrease the impacts of the pandemic on society.

In addition to the huge help in the diagnosis, many Brazilian scientists are working in several research projects about SARS-CoV-2 and COVID-19, including the development of diagnostic kits, testing of drugs and vaccines, and on the production of personal protective equipment and respirators.

\section{SARS-CoV-2 in animals}

Coronaviruses are known to infect wild and domestic animals, where bats act as a reservoir for different $\mathrm{CoV}$ genera and species (Banerjee et al., 2019). Alpha and beta-CoVs are frequently reported in mammals, while delta and gamma-CoV are more frequently reported in birds. SARS-CoV-1 was the first CoV known to have inflicted severe disease in humans. It is likely that SARS-CoV-1 has an evolutionary origin in horseshoe bats (Rhinolophus spp.) (Wong et al., 2019), but as this virus was also found in captive cat civets (Civettictis civetta) and raccoon dogs (Nyctereutes procyonoides) in markets and some farms, it is believed that these species might have acted as intermediate hosts for SARS-CoV-1 (Guan et al., 2003; Kan et al., 2005).

SARS-CoV-2 is phylogenetically closely related to SARS$\mathrm{CoV}-1$, and it has been classified in the same betacoronavirus species; besides, early genomic comparisons revealed that the most closely related viruses to SARS-CoV-2 came from bats (Zhou et al., 2020). Although bats are likely to be the reservoir and host for this virus, their general ecological separation from humans makes it probable that other mammalian species act as intermediate or amplifying hosts, within which SARS-CoV-2 was able to acquire some or all of the mutations needed for efficient human transmission (Zhang and Holmes, 2020). 
According to Zang and Holmes (2020), to determine what these intermediate host species might be, it is imperative to perform a much wider sampling of animals from wet markets or that live close to human populations. Moreover, other SARS-CoVs were reported in different bat species worldwide (Góes et al., 2013).

SARS-CoV-2 spread in Brazil initially affecting the Southeastern, Northeastern and Northern regions. The Southeastern region has high demographic density, whereas the other two regions present poorer sanitation and public healthcare conditions. Of great concern is the spreading to the Amazon region, which combined with alarming levels of deforestation, poses an enormous threat to native indigenous tribes and creates conditions for this virus to come in contact with wildlife (Ellwanger et al., 2020). Brazil presents around 184 bat species, and such species richness is similar to that found in the Southeast of Asia; albeit adaptation to a novel host and a zoonotic establishment is a complex multifactorial process, this fact should be considered when predicting the risk of the perpetuation of SARS-CoV-2 in South America (Han et al., 2016).

This scenario is considered in North America (Franklin and Bevins, 2020) where bat diversity, contact with humans and richness are far lower than in Brazil, therefore this form of perpetuation should be monitored in the future in Brazil as well. Currently, few studues are searching for $\mathrm{CoV}$ in Brazilian bats, where only alpha-CoV was found to date (Góes et al., 2013). The wide variety of beta-CoV found in bats worldwide combined with the heterogeneity of Brazilian bats may be a potential source of $\mathrm{CoV}$ investigation.

Recent research shows the presence of viruses closely related to SARS-CoV-2 in Malayan pangolins (Manis javanica), that are of great interest since they are frequently involved in illegal trafficking and their endangered status. Moreover, the recent studies that showed that they can carry viruses closely-related to SARS-CoV-2 suggest a far greater diversity of related betacoronaviruses in a variety of mammalian species. However, to fully understand the extent of hosts and the diversity of betacoronaviruses circulating, animal samples need to be further investigated. On the other hand, some authors report that the potential amplifying mammalian host, intermediate between bats and humans, is unknown.

Since the mutation in the original strain could directly have triggered virulence towards humans, it is not certain that this intermediary exists (Cascella et al., 2020). Many uncertainties due to lack of data remain for the actual hosts of SARS-CoV-2 and their zoonotic characteristics, showing the importance of including monitoring and surveillance of this virus in wild animals. As a way to minimize these uncertainties, Becker et al. (2020) carried out a study proposing predictions models that could help to guide sampling for novel potentially zoonotic viruses, immunological research to characterize key receptors (e.g., ACE2) and identify mechanisms of viral tolerance, and experimental infections to quantify competence of suspected host species.

It has been experimentally shown that among animals, felids and mustelids are permissive to SARS-CoV-2 infection, while dogs, pigs, chickens and ducks are not as susceptible (Shi et al., 2020). A recent outbreak of SARS-CoV-2 in mink farms in the Netherlands raised serious concerns about the susceptibility of this taxon to SARS-CoV-2 disease (Oreshkova et al., 2020). Differently to what was reported in felids, in which only mild disease in a low number of animals was observed, the outbreak in Dutch minks presented cases of severe pneumonia, mortality and a high number of infected animals.

This example raises concerns about possible spillover between humans and these mustelids, since there are six genera from the Mustelidae family in South America and more than a dozen species of felids. With the current anthropogenic disturbance of the habitats of these animals in Brazil, there is a risk of infection of endangered species and spillover events that could perpetuate SARS-CoV-2 in nature and allow new mutations and possible new viral variants to occur as the virus interacts with new hosts and is challenged with a different immunological response (Ellwanger et al., 2020). Moreover, the high pressure of infection during the SARS-CoV-2 pandemic may allow a putative permissive new host adaptation.

\section{SARS-CoV-2 in aquatic environments}

Human enteric viruses (which are non-enveloped viruses) are known as the main pathogens that cause waterborne diseases. Among the diseases, we could mention gastrointestinal, conjunctivitis, respiratory symptoms and viral hepatitis. On the other hand, enveloped viruses behave differently in the aquatic environment. In general, these viruses are not considered as a major threat to the wastewater and water industries due to their supposedly low concentration and high susceptibility to degradation in the aquatic environment. However, several clinical reports show that certain enveloped viruses are excreted in the faeces during infection (Wigginton et al., 2015).

The transmission mode of SARS-CoV-2 occurs through person-to-person contact through respiratory droplets, sneezing, coughing, direct contact with an infected individual, or indirect contact through fomites. Water transmission has never been demonstrated in humans, but since SARS-CoV-2 was found in stool samples (Holshue et al., 2020; Xiao et al., 2020) the possibility of fecal-oral transmission needs to be clarified. La Rosa et al. (2020a) carried out a review work to investigate publications on $\mathrm{CoV}$ in aquatic environments. The authors mainly reported that: $\mathrm{CoV}$ appears to be inactivated faster in water than non-enveloped human enteric viruses; temperature is an important factor influencing viral survival (the infectious viral titer decreases more quickly at $23{ }^{\circ} \mathrm{C}$ and $25^{\circ} \mathrm{C}$ than at $4{ }^{\circ} \mathrm{C}$ ), and so far, there is no evidence that $\mathrm{CoV}$ is present in surface or groundwater or that it is transmitted through contaminated drinking water.

According to the Centers for Disease Control and Prevention (CDC), so far, SARS-CoV-2 has not been detected in drinking water, since conventional water treatment methods that use filtration and disinfection used in public drinking water treatments are efficient on virus removal or inactivation. Also, the CDC states that there is no evidence that the virus can be transmitted to people through the water in swimming pools, hot tubs or water playgrounds.

This is possible as long as adequate water disinfection is performed, thus ensuring viral inactivation. It is worth mentioning that everyone should follow state, local, territorial or tribal guidance that might determine when and how public 
pools, hot tubs or water playgrounds may operate and might include CDC considerations (CDC, 2020b).

In addition to the respiratory symptoms caused by COVID-19, a varied percentage of patients (between 16\% and $73 \%$ ) have reported diarrhea as an additional symptom. Furthermore, recent studies show the presence of SARS-CoV-2 genetic material in patients' stool samples (Holshue et al., 2020; Xiao et al., 2020; Xu et al., 2020). Several studies in many countries, such as Netherlands (Medema et al., 2020), United States (Wu et al., 2020), Australia (Ahmed et al., 2020), France (Wurtzer et al., 2020) and Italy (La Rosa et al., 2020b) have demonstrated the occurrence of SARS-CoV-2 in municipal wastewater.

Although no studies are showing SARS-CoV-2 transmission by wastewater, the increase in the viral circulation in the population overloads municipal sewage systems. Thus, it is worth highlighting the importance of viral monitoring in these environments, so that it is possible to obtain information on the risk for workers from the wastewater treatment plant and also to monitor the circulation of SARS-CoV-2 in the community, thus complementing clinical surveillance (Medema et al., 2020).

In Italy, La Rosa et al. (2020b) evaluated the presence of SARS-CoV-2 RNA in 12 sewage samples collected between February and April 2020 at the wastewater treatment plants in Milan and Rome of high and low endemic circulation areas, respectively. Overall, 6 of the 12 samples were positive, one of which was obtained from Milan wastewater collected a few days after the first Italian case of COVID-19. Medema et al. (2020) conducted a study on sewage samples in seven cities in the Netherlands using the RT-PCR method. No positive SARS-CoV-2 samples were detected on February $6^{\text {th }}$, three weeks before the first case was reported in the Netherlands, on February $27^{\text {th }}$. On the other hand, in general, between March $5^{\text {th }}$ and $16^{\text {th }}$, positive samples were detected in six sites.

In France, Wurtzer et al. (2020) carried out a study on samples collected from the wastewater treatment plant of the Parisian area from March $5^{\text {th }}$ to April $23^{\text {rd }}, 2020$ (including the lockdown period since March $17^{\text {th }}, 2020$ ). They reported that the increase of genome units in raw wastewaters accurately followed the increase of human COVID-19 cases observed at the regional level and that the viral genomes fragments $(\mathrm{E}$ gene) could be detected before the beginning of the exponential growth of the epidemic. The authors also claim that a marked decrease in the quantities of genomes units was observed concomitantly with the reduction in the number of new COVID-19 cases as an expected consequence of the lockdown.

Many cities in Brazil do not receive proper sanitation infrastructures nor have proper sewage treatment before it is disposed of back into the watersheds, and several infectious agents have been detected in water, which is a source of microbial source tracking in different environments (Spilki et al., 2013). Hence, SARS-CoV-2 detection in wastewater and in watersheds may occur in Brazil, offering another source to assess viral spread.

\section{Conclusion}

Brazil had around two months to prepare strategies to face the COVID-19 pandemic, and considering the time and the other countries' examples that were affected first, it could have had better results, which it did not happen. Brazil is a developing country with a large social inequality and now, besides a sanitary crisis, it is also facing a political crisis. During the pandemic, two Health Ministers were withdrawn from their position, and until now (June 26th, 2020) no other Minister was appointed yet. As the country presents high numbers of cases and deaths by COVID-19, it is still well known that there is a large number of unreported cases.

Another problem is that while the number of positive cases of COVID-19 increased, there was a decrease in social distancing, an unusual event. Moreover, Brazil presents a plethora of putative wild animal candidates to harbor a possible spillover, including mainly bats, rodents, and mustelids. The anthropogenic disturbance of wildlife habitats added to the environmental contamination may be a potential risk factor that must not be ignored. Reducing deforestation combined with continuous evaluation of the betacoronaviruses circulation on these species may be a potential prevention measure to avoid new outbreaks with a zoonotic origin.

\section{Acknowledgements}

We would like to thank the Brazilian Coordinating Agency for Advanced Training of Graduate Personnel (CAPES), Brazilian National Council for Scientific Development (CNPq), Financier of Studies and Projects (FINEP), Brazilian Ministry of Sciences and Innovation and Dimensions Science for support and scholarships.

\section{Conflict of Interest}

The authors declare that there are no conflicts of interest.

\section{Authors Contributions}

MD, JSG, VG, PRA, MNW and AKAE literature revision and writing. JDF and FRS writing, review and editing. All authors read and approved the final version.

\section{References}

Ahmed W, Angel N, Edson J, Bibby K, Bivins A, O’Brien JW, Choi PM, Kitajima M, Simpson SL, Li S et al. (2020) First confirmed detection of SARS-CoV-2 in untreated wastewater in Australia: A proof of concept for the wastewater surveillance of COVID-19 in the community. Sci Total Environ 728:138764.

Banerjee A, Kulcsar K, Misra V, Frieman M and Mossman K (2019) Bats and coronaviruses. Viruses 11:7-9.

Becker DJ, Albery GF, Sjodin AR, Poisot T, Dallas TA, Eskew EA, Farrell MJ, Guth S, Han BA, Simmons NB et al. (2020) Predicting wildlife hosts of betacoronaviruses for SARSCoV-2 sampling prioritization. bioRxiv 2020.05.22.111344.

Bedford J, Enria D, Giesecke J, Heymann DL, Ihekweazu C, Kobinger G, Lane HC, Memish Z, Oh M, Sall AA et al. (2020) COVID-19: towards controlling of a pandemic. Lancet 395:1015-1018.

Candido DS, Watts A, Abade L, Kraemer MUG, Pybus OG, Croda J, Oliveira W, Khan K, Sabino EC and Faria NR (2020) Routes for COVID-19 importation in Brazil. J Travel Med 27:1-3.

Cascella M, Rajnik M, Cuomo A, Scott C, Dulebohn SC and Napoli RD (2020) Features, Evaluation, and Treatment Coronavirus (COVID-19). StatPearls, Treasure Island.

Chan KH, Peiris JSM, Lam SY, Poon LLM, Yuen KY and Seto WH (2011) The effects of temperature and relative humidity on the viability of the SARS coronavirus. Adv Virol 2011:734690. 
Chin AWH, Chu JTS, Perera MRA Hui KPY, Yen HY, Chan MCW, Peiris M and Poon LLM (2020) Stability of SARS-CoV-2 in different environmental conditions. Lancet Microbe 1:e10.

Cui J, Li F and Shi ZL (2019) Origin and evolution of pathogenic coronaviruses. Nat Rev Microbiol 17:181-192.

de Oliveira SB, Pôrto VBG, Ganem F, Mendes FM, Almiron M, de Oliveira WK, Fantinato FFST, Almeida WAF, Borges APM Junior, Pinheiro HNB et al. (2020) Monitoring social distancing and SARS-CoV-2 transmission in Brazil using cell phone mobility data. Medrxiv:2020.04.30.20082172

Ellwanger JH, Kulmann-Leal B, Kaminski VL, Valverde-Villegas JM, Veiga ABG, Spilki FR, Fearnside PM, Caesar L, Giatti LL, Wallau GL, et al. (2020) Beyond diversity loss and climate change: Impacts of Amazon deforestation on infectious diseases and public health. An Acad Bras Cienc 92:e20191375.

Franklin AB and Bevins SN (2020) Spillover of SARS-CoV-2 into novel wild hosts in North America: A conceptual model for perpetuation of the pathogen. Sci Total Environ 733:139358.

Góes LGB, Ruvalcaba SG, Campos AA, Queiroz LH, Carvalho C, Jerez JA, Durigon, EL, Dávalos LII and Dominguez SR (2013) Novel bat coronaviruses, Brazil and Mexico. Emerg Infect Dis 19:1711-1713.

Gorbalenya AE, Baker SC, Baric RS, Groot RJ, Drosten C, Gulyaeva AA, Haagmans BL, Lauber C, Leontovich AM, Neuman BW et al. (2020) The species Severe acute respiratory syndromerelated coronavirus: classifying $2019-\mathrm{nCoV}$ and naming it SARS-CoV-2. Nat Microbiol 5:536-544.

Guan Y, Zheng BJ, He YQ, Liu XL, Zhuang ZX, Cheung CL, Luo SW, Li PH, Zhang LJ, Guan YJ et al. (2003) Isolation and characterization of viruses related to the SARS coronavirus from animals in Southern China. Science 302:276-278.

Han BA, Kramer AM and Drake JM (2016) Global Patterns of Zoonotic Disease in Mammals. Trends Parasitol 32:565-577.

Holshue ML, DeBolt C, Lindquist S, Lofy KH, Wiesman J, Bruce H, Spitters C, Ericson K, Wilkerson S, Tural A et al. (2020) First case of 2019 novel coronavirus in the United States. N Engl J Med 382:929-936.

Jin YH, Cai L, Cheng ZS, Cheng H, Deng T, Fan Y, Fang C, Huang D, Huang L, Huang Q et al. (2020) A rapid advice guideline for the diagnosis and treatment of 2019 novel coronavirus (2019-nCoV) infected pneumonia (standard version). Mil Med Res 7:4.

Kan B, Wang M, Jing H, Xu H, Jiang X, Yan M, Liang W, Zheng H, Wan K, Liu Q et al. (2005) Molecular evolution analysis and geographic investigation of Severe Acute Respiratory Syndrome Coronavirus-like Virus in Palm Civets at an animal market and on farms. J Virol 79:11892-11900.

La Rosa G, Bonadonna L, Lucentini L, Kenmoe S and Suffredini E (2020a) Coronavirus in water environments: Occurrence, persistence and concentration methods - A scoping review. Water Res 179:115899.

La Rosa G, Iaconelli M, Mancini P, Ferraro GB, Veneri C, Bonadonna L, Lucentini L and Suffredini E (2020b) First detection of SARS-CoV-2 in untreated wastewaters in Italy. Sci Total Environ 736:139652.

Lescure FX, Bouadma L, Nguyen D, Parisey M, Wicky P, Behillil S, Gaymard A, Bouscambert-Duchamp M, Donati F, Hingrat QL et al. (2020) Clinical and virological data of the first cases of COVID-19 in Europe: a case series. Lancet Infect Dis 20:697-706.

Medema, G, Heijnen, L, Elsinga, G, Italiaander, R and Brouwer, A (2020). Presence of SARS-Coronavirus-2 RNA in sewage and correlation with reported COVID-19 prevalence in the early stage of the epidemic in the Netherlands. Environ Sci Technol Lett 7: 511-516.
Mellan, TA, Hoeltgebaum, HH, Mishra, S, Whittaker, C, Schnekenberg, RP, Gandy, A, Unwin JT, Vollmer MAC, Coupland H, Hawryluk I et al. (2020). Report 21: Estimating COVID-19 cases and reproduction number in Brazil. medRxiv:2020.05.09.20096701.

Oreshkova N, Molenaar R-J, Vreman S, Harders F, Munnink BBO, Hakze R, Gerhards N, Tolsma P, Bouwstra R, Sikkema R et al. (2020) SARS-CoV2 infection in farmed mink, Netherlands, April 2020. bioRxiv: 2020.05.18.101493.

Prata DN, Rodrigues W and Bermejo PH (2020) Temperature significantly changes COVID-19 transmission in (sub)tropical cities of Brazil. Sci Total Environ 729:138862.

Rezende LFM, Thome B, Schveitzer MC, Souza-Júnior PRB and Szwarcwald CL (2020) Adults at high-risk of severe coronavirus disease-2019 (Covid-19) in Brazil. Rev Saude Publ 54:50.

Rodriguez-Morales AJ, Gallego V, Escalera-Antezana JP, Méndez CA, Zambrano LI, Franco-Peredes C, Suárez JA, RodriguezEnciso HD, Balbin-Ramon GJ, Silvio-Larriera E et al. (2020) COVID-19 in Latin America: The implications of the first confirmed case in Brazil. Travel Med Infect Dis 35:101613.

Shi J, Wen Z, Zhong G, Yang H, Wang C, Huang B, Liu R, He X, Shuai L, Sun Z et al. (2020). Susceptibility of ferrets, cats, dogs, and other domesticated animals to SARS-coronavirus 2. Science 368:1016-1020.

Souza WM, Buss LF, Candido DS, Carrera J-P, Li S, Zarebski AE, Vincenti-Gonzalez MF, Messina J, Sales FCS, Andrade PS, Prete CA et al. (2020) Epidemiological and clinical characteristics of the early phase of the COVID-19 epidemic in Brazil. medRxiv:2020.04.25.20077396

Spilki FR, da Luz RB, Fabres RB, Soliman MC, Kluge M, Fleck JD, Rodrigues MT, Comerlato J, Cenci A, Cerva C et al. (2013) Detection of human adenovirus, rotavirus and enterovirus in water samples collected on dairy farms from Tenente Portela, Northwest Of Rio Grande do Sul, Brazil. Braz J Microbiol 44:953-957.

Tu YF, Chien CS, Yarmishyn AA, Lin Y-Y, Luo Y-H, Lin Y-T, Lai W-Y, Yang D-M, Chou S-J, Yang Y-P et al. (2020) A review of SARS-CoV and the ongoing clinical trials. Int J Mol Sci 21:2657.

Van Doremalen N, Bushmaker T, Morris DH, Holbrook MG, Gamble A, Williamson BN, Tamin A, Harcourt JL, Thornburg NJ, Gerber SI et al. (2020) Aerosol and surface stability of SARS-CoV-2 as compared with SARS-CoV-1. N Engl J Med 382:1564-1567.

Wells CR, Sah P, Moghadas SM, Pandey A, Shoukat A, Wang Y, Wang Z, Meyers LA, Singer BH and Galvani AP (2020) Impact of international travel and border control measures on the global spread of the novel 2019 coronavirus outbreak. Proc Natl Acad Sci U S A 117:7504-7509.

Wigginton KR, Ye Y and Ellenberg RM (2015) Emerging investigators series: The source and fate of pandemic viruses in the urban water cycle. Environ Sci Water Res Technol 1:735-746.

Wilder-Smith A and Freedman DO (2020) Isolation, quarantine, social distancing and community containment: pivotal role for old-style public health measures in the novel coronavirus (2019-nCoV) outbreak. J Travel Med 27:1-4.

Wong ACP, Li X, Lau SKP and Woo PCY (2019) Global epidemiology of bat coronaviruses. Viruses 11:174.

Wu F, Xiao A, Zhang J, Gu XQ, Lee WL, Kauffman K, Hanage WP, Matus M, Ghaeli N, Endo N et al. (2020) SARS-CoV-2 titers in wastewater are higher than expected from clinically confirmed cases. mSystems 5:e0614-20.

Wurtzer S, Marechal V, Mouchel JM, Maday Y, Teyssou R, Richard E, Almayrac JL and Moulin L (2020) Time course quantitative detection of SARS-CoV-2 in Parisian wastewaters correlates with COVID-19 confirmed cases. medRxiv:2020.04.12.20062679 
Xiao F, Tang M, Zheng X, Liu Y, Li X and Shan H (2020) Evidence for Gastrointestinal Infection of SARS-CoV-2. Gastroenterology 158:1831-1833.e3.

Xu Y, Li X, Zhu B, Liang H, Fang C, Gong Y, Guo Q, Sun X, Zhao $\mathrm{D}$, Shen J et al. (2020) Characteristics of pediatric SARS$\mathrm{CoV}-2$ infection and potential evidence for persistent fecal viral shedding. Nat Med 26:502-505.

Zhang YZ and Holmes EC (2020) A Genomic Perspective on the Origin and Emergence of SARS-CoV-2. Cell 181:223-227.

Zhou P, Yang X Lou, Wang XG, Hu B, Zhang L, Zhang W, Si H, Zhu Y, Li B et al. (2020) A pneumonia outbreak associated with a new coronavirus of probable bat origin. Nature 579:270-273.

\section{Internet Resources}

ANVISA (2020) Protocolo - Detecção e atendimento de casos suspeitos da COVID-19 em portos, aeroportos e fronteiras. http://portal.anvisa.gov.br/documents/219201/5777769/ protocolo+-+detecção+e+atendimento+de+casos+suspeitos + + em+paf/c59c95d1-53f0-45e4-a91a-00e957086183 (accessed May 2, 2020).

CDC (2020a) Global COVID-19 Pandemic Notice, https://wwwnc. cdc.gov/travel/notices/warning/coronavirus-global (accessed June 10, 2020).

CDC (2020b) Coronavirus Disease 2019 (COVID-19), https://www. cdc.gov/coronavirus/2019-ncov/faq.html?cdc_aa_refval= https $\% 3 \mathrm{a} \% 2 \mathrm{f} \% 2 \mathrm{fwww} . \mathrm{fdc}$.gov\%2fcoronavirus $\% 2 \mathrm{f} 2019$ ncov\%2fphp\%2fwater.html\#covid-19-and-water (accessed June 17, 2020).

Governo Federal do Brasil (2020) Portaria n. 152, de 27 de março de 2020, http://www.in.gov.br/en/web/dou/-/portaria-n-152de-27-de-marco-de-2020-250060288 (accessed May 2, 2020)
Inloco (2020) Mapa brasileiro da COVID-19, https://mapabrasileiro dacovid.inloco.com.br/pt/ (accessed June 27, 2020).

Ministério da Saúde do Brasil (2020) Boletim Epidemiológico Especial - COE-COVID19, https://saude.gov.br/images/ pdf/2020/august/19/boletim-epidemiologico-covid-27.pdf (accessed September 9, 2020).

WHO (2020a) WHO Director-General's opening remarks at the media briefing on COVID-19 - 11 March 2020, https://www. who.int/dg/speeches/detail/who-director-general-s-openingremarks-at-the-media-briefing-on-covid-19---11-march-2020 (accessed June 10, 2020).

WHO (2020b) WHO Coronavirus Disease (COVID-19) Dashboard, https://covid19. who.int/?gclid=cjwkcajwxev3brbbeiwaib pwbptrp7ym3acdpi9zlp-y_nf1jo9gur0bgdeeaibg-obwh6miyy1rocppaqavd bwe (accessed September 09, 2020).

WHO (2020c) Coronavirus disease COVID-2019, https://www. who.int/docs/default-source/coronaviruse/situationreports/20200602-covid-19-sitrep-134.pdf?sfvrsn $=$ cc95e5d5 2 (accessed June 10, 2020).

Associate Editor: Diogo Meyer

License information: This is an open-access article distributed under the terms of the Creative Commons Attribution License (type CC-BY), which permits unrestricted use, distribution and reproduction in any medium, provided the original article is properly cited. 